\title{
Antimicrobial Properties of Orange (Citrus reticulata var. Kinnow) Peel Extracts against Pathogenic Bacteria
}

\author{
P. Yashaswini* and Arvind \\ Centre of Food Science and Technology, Institute of Agricultural Sciences, \\ Banaras Hindu University, Varanasi, India \\ *Corresponding author
}

\section{A B S T R A C T}

\begin{tabular}{l} 
K e y w o r d s \\
$\begin{array}{l}\text { Antibacterial activity, } \\
\text { Zone of inhibition, } \\
\text { Minimum inhibitory } \\
\text { concentration, Citrus } \\
\text { reticulate var Kinnow, } \\
\text { Peel extracts }\end{array}$ \\
\hline Article Info \\
$\begin{array}{l}\text { Accepted: } \\
\text { 07 February } 2018 \\
\text { Available Online: } \\
\text { 10 March } 2018\end{array}$
\end{tabular}

\section{Keywords}

Antibacterial activity, Zone of inhibition

Minimum inhibitory concentration, Citrus Peel extracts

10 March 2018
Citrus peels are known for the abundant amounts of polyphenols present, which have been proven to possess antimicrobial activity. The objective of this project was to determine the phenolic content and antibacterial capacity of orange (Citrus reticulata var. Kinnow) peel extracts against pathogenic strains of Staphylococcus aureus, Escherichia coli, Pseudomonas aeruginosa, and Klebsiella pneumoniae. Peel powder of Orange was subjected to polyphenolic extraction using different solvents viz., petroleum ether, ethanol, acetone, and methanol. Pathogenic bacterial strains of Staphylococcus aureus, Escherichia coli, Pseudomonas aeruginosa, and Klebsiella pneumoniae were screened for the antibacterial activity of the extracts using disc diffusion technique. The total phenolic content of the extracts was determined by the method involving Folin-Ciocalteau reagent and gallic acid standards, and was expressed as mg GAE/ml extract. As compared to other solvent extracts, acetone extract possessed high phenolic content with $17.6 \mathrm{mg} \mathrm{GAE} / \mathrm{ml}$ of extract. It was also noticed that acetone extract possessed comparatively higher antibacterial potential, and it was shown to inhibit all four pathogenic bacterial strains. The Minimum Inhibitory concentration (MIC) of $68.75 \mu \mathrm{g} / \mathrm{ml}$ of acetone extract was found to inhibit Klebsiella pneumoniae and Escherichia coli, with no significant difference. Maximum zone of inhibition at MIC of acetone was found to be $7.93 \pm 0.065 \mathrm{~mm}$ in case of K. pneumoniae and $7.75 \pm 0.12 \mathrm{~mm}$ in E. coli.

\section{Introduction}

In the recent years, there has been a profound shift in the preference for natural substances as antimicrobials. The prevalence of antibiotic resistance is a continual problem due to the evolution of a potent defense mechanism against antibiotics. Therefore, it is necessary to exploit and develop novel inhibitory agents against resistant microbial pathogens (Otang and Afolayan, 2015). Plants can produce antimicrobial compounds to protect themselves from biotic attack that could be essential for microbial infection resistance. Also, it has been proven that antimicrobials and antibiotics from plant sources work more efficiently with fewer side-effects and added beneficial effects (Khushwaha et al., 2012).

Plant based extracts with potential antimicrobial activity are being researched and tested to replace antibiotic drugs used for 
inhibiting pathogens. Natural antimicrobials, whether of animal, plant or microbial origin, which exhibit bacteriostatic or bactericidal effects lengthen the life of products they are incorporated into, and also reduce, if not completely avoid health-related issues (ViudaMartos et al., 2008).

Citrus species are known for an abundance of bioactive components, nutraceuticals, and functional compounds in the flavedo and albedo of the peels. In Citrus fruits, flavonoids are present as flavanones (neohesperidosides, rutinosides), flavanol glycosides, flavones (polymethoxyflavones, hydroxylated polymethoxyflavones) with predominant bioactive compounds like naringin and hesperidin (Escobedo-Avellaneda et al., 2014; Ramful et al., 2011). Phenolic compounds like flavonoids are known to exhibit antioxidant, antiatherogenic, anti-inflammatory, anticarcinogenic, antiviral, antimicrobial and antiallergenic activities (Escobedo-Avellaneda et al., 2014)

Certain Citrus species have the antibacterial potential against clinically significant bacterial strains. It was found that acid-hydrolyzed Citrus unshiu peel extract inhibited Bacillus cereus, Staphylococcus aureus and Listeria monocytogenes (Keun Young Min et al., 2014). As an antimicrobial agent, these polyphenols can penetrate the semi permeable cell membrane where they react with the cytoplasm or cellular proteins (Sa et al., 2015)

The objective of this study was to determine the antibacterial potential of extracts of methanol, ethanol, acetone and petroleum ether from Citrus reticulata var. Kinnow against pathogenic strains of Staphylococcus aureus, Escherichia coli, Pseudomonas aeruginosa, and Klebsiella pneumoniae and to determine the MIC and Zone of Inhibition of the bacteria.

\section{Materials and Methods}

\section{Materials}

\section{Microorganisms}

The extracts were screened for their antibacterial activities against various pathogenic bacterial strains, gram negative and gram positive, namely Staphylococcus aureus, Escherichia coli, Pseudomonas aeruginosa, and Klebsiella pneumoniae, provided by the Department of Microbiology, Institute of Medical Sciences, Banaras Hindu University.

\section{Chemicals and apparatus}

All chemicals and media were procured from Merck and Hi-media respectively. The plates used for experimentation were irradiated disposable Tarsonspetriplates and Eppendorf tubes for extracts.

\section{Preparation of orange peel powder}

Orange peels of Citrus reticulata var. Kinnow procured from the local fruit vendors was first washed thoroughly to remove any extraneous matter and to get rid of contaminants. It was then subjected to blanching operation and pressed to remove excess water. They were cut into $1 \mathrm{x} 1$ inch size, placed on a tray and dried in a tray drier at a constant temperature of $40^{\circ} \mathrm{C}$. When peels were dried to a moisture content $<5 \%$, it was finely pulverized in a sterile grinder and sieved. It was then stored in air tight sealed PE-PA bags and placed at $4^{\circ} \mathrm{C}$.

\section{Preparation of extracts}

Orange peel extracts were prepared according to the method by Yadav et al., (2015) with slight modifications. $4 \mathrm{~g}$ of Orange Peel Powder, stored at $4{ }^{\circ} \mathrm{C}$, was taken in 4 different conical flasks. $20 \mathrm{ml}$ of ethanol, methanol, 
acetone, and petroleum ether was added respectively. The conical flasks were tightly stoppered with plugs of non-absorbent cotton and this was wrapped with aluminium foil as a precautionary measure. The conical flasks were placed in a shaker incubator pre-set at $30^{\circ} \mathrm{C}$ at $130 \mathrm{rpm}$ for 36 hours for extraction to complete. After the extraction process was completed, the flasks were removed from the incubator and the contents were poured into centrifuge tubes (Tarson Tubes) that were tightly capped and were centrifuged at 4200 $\mathrm{rpm}$ at $10^{\circ} \mathrm{C}$. The clear liquids were immediately transferred to clean, dry petriplates and were placed in a tray drier at $35^{\circ} \mathrm{C}$ to concentrate it up to $80 \%$ and to ensure that the solvent used for extraction evaporated. The centrifuge tubes with pellets were discarded. When most of the solvents had evaporated, the extracts were carefully transferred into small Eppendorf tubes and stored at $10^{\circ} \mathrm{C}$.

\section{Total Phenolic Content (TPC) assay}

The Total Phenolic Content of the extracts was determined by the method involving Folin-Ciocalteau reagent and Gallic acid standards (Hinneburg et al., 2006). Gallic acid was used for generating the standard curve having concentrations ranging from 20 to 100 $\mathrm{mg} / \mathrm{ml}$. $2.5 \mathrm{ml}$ of 10 times diluted FC reagent was added to each tube and mixed well for 1 min and $2 \mathrm{ml}$ of $7.5 \% \mathrm{Na}_{2} \mathrm{CO}_{3}$ was added to it and allowed to incubate for 30 minutes at 37 ${ }^{\circ} \mathrm{C}$ and further the absorbance was measured at $760 \mathrm{~nm}$ in ultraviolet- 1800 spectro photometer (Shimadzu, Kyoto, Japan) and standard graph was plotted.

The reaction mixture was also incubated at 37 ${ }^{\circ} \mathrm{C}$ for $30 \mathrm{~min}$ and the absorbance was recorded at $760 \mathrm{~nm}$. All procedures were performed with three replicates. The total phenolic content equivalent to Gallic acid was determined from standard graph. It was expressed as Gallic Acid Equivalents per gm of dry extract (mg GAE/g).

\section{Antimicrobial testing}

\section{Preparation of inoculum}

The bacterial isolates procured were inoculated in Mueller-Hinton Agar (MHA, Hi Media) and were incubated at $37^{\circ} \mathrm{C}$ for $3-7$ hours until the culture attained turbidity to the Mc Farland Std no. $0.5\left[\sim 10^{6}\right.$ colony forming units CFU/ml]. (Singh et al., 2014)

\section{Determination of sensitivity of orange peel extract against pathogenic bacteria}

The sensitivity of peel extract against four pathogens namely Staphylococcus aureus, Salmonellatyphii, Klebsiella spp., and Escherichia coliwas performed according to protocol of Yadav et al., (2015). Mueller Hinton Agar (MHA, Hi-Media) was prepared, autoclaved, and poured into sterile petriplates (Tarsons Irradiated Disposable). The Orange peel extracts, which were tray-dried at $35^{\circ} \mathrm{C}$, were dissolved in respective solvents in the ratio of 2:1 and $10 \mu \mathrm{l}$ of extract solution was dropped onto petri plates (Tarsons-Irradiated Disposable Plates) swabbed with bacterial inoculum. The controls, which consisted of respective solvents for extracts, was set up next to the extract and $10 \mu \mathrm{l}$ of control was dropped adjacent to the spot of the extract. The plates were then incubated for 24 hours at $37^{\circ} \mathrm{C}$. The clear zone around the drop of the extract was noticed.

\section{Determination of minimum inhibitory concentration of extract against pathogenic bacteria}

Solutions of the extracts were prepared for initial stock solution at a ratio of 1:1. From this stock solution, serial dilutions of the compound were prepared up to 10 dilutions to 
determine the Minimum Inhibitory Concentration. $0.5 \mathrm{ml}$ of each of the diluted extract was dropped sequentially on to the prepared plates, after placing sterile Whatman no. 1 filter paper discs ( $5 \mathrm{~mm}$ diameter).Sterile distilled water was used as a negative control. The plates were inverted and incubated for 24 hours at $37^{\circ} \mathrm{C}$. Antimicrobial activity was evaluated by measuring the diameter of inhibition zones with no bacterial growth in $\mathrm{mm}$. The minimum inhibitory concentration (MIC) was defined as the lowest concentration where no viability was observed after $24 \mathrm{~h}$ on the basis of zones of growth. All the determinations were conducted in triplicates (Singh et al., 2014). The serial dilutions of the four different extracts have been tabulated in Table 1.

\section{Statistical analysis}

All data was expressed as mean \pm standard errors of triplicate measurements. Statistical significance was tested by employing one- way analysis of variance and comparison between means was made with the help of Microsoft excel 2016.

\section{Results and Discussion}

\section{Total phenolic content}

The highest phenolic content was found in the acetone extract of Orange peel with $17.6 \mathrm{mg}$ $\mathrm{GAE} / \mathrm{ml}$ of extract, followed by methanol extract which contained $12.5 \mathrm{mg}$ GAE/ml extract. This is in agreement with a study conducted by Yadav et al., (2015), where it was found that acetone was a better solvent for the extraction polyphenols from different grape fractions. It was propounded by Alothman et al., (2009) that the recovery of phenolic compounds was purely dependent on the solvent used and its polarity for the different plant materials it is used for. The recovery of polyphenolic compounds from plant materials is affected by their solubility in that specific solvent. Also, the solvent solubility plays a pivotal role in increasing the phenolic compounds solubility in it (Alothman et al., 2009). The solvent which has the highest polyphenol content possesses maximum extractability of the compounds in comparison to the other solvents (Yadav et al., 2015). The maximum predicted Total Phenolic Content comprising primarily of bioactive polyphenols from Citrus sinensis under the optimal Microwave Assisted Extraction (MAE) conditions with $51 \%$ acetone concentration in water $(\mathrm{v} / \mathrm{v}), 122 \mathrm{~s}$ extraction time and $25 \mathrm{~mL} / \mathrm{g}$ solvent to solid ratio) was $12.20 \mathrm{mg} \mathrm{GAE} / \mathrm{g}$ dry weight, which was ideal (Nayak et al., 2015). In a study conducted by Alothman et al., (2009) where phenolic content was determined for different tropical fruits using different solvents for extraction, it was found that for pineapple extracts, 50\% acetone and $70 \%$ ethanol gave the highest yield for total phenolics without significant differences between them.

In a study conducted for the determination of effects of different solvents extraction on concentration and antioxidant activity of black and black mate tea polyphenols, it was found that for black mate tea, $50 \%$ acetone showed the highest polyphenol content (Turkmen et al., 2006).

The ethanolic extract contained $10.25 \mathrm{mg}$ $\mathrm{GAE} / \mathrm{ml}$ in the present study, which is a fairly good extraction potential. It has been stated that ethanolic mixtures and extracts have a higher acceptability for human consumption models (Alothman et al., 2009). In a study conducted for the extraction of polyphenols from grapes marc, ethanol and methanol extracts of red and black currant contain twice more anthocyanins and polyphenols than water extracts, extracts made from grape marc had seven times higher values than water extracts (Lapornik et al., 2005). 
Table.1 Serial dilution of extract for the determination of MIC for pathogenic bacteria inhibition

\begin{tabular}{|c|c|c|c|c|c|c|c|c|c|c|c|}
\hline \multirow[t]{2}{*}{ Extract } & \multirow{2}{*}{$\begin{array}{c}\text { Initial } \\
\text { Concentration } \\
\text { (mg GAE/ml } \\
\text { extract) }\end{array}$} & \multicolumn{10}{|c|}{ Serial Dilutions used for determination of MIC $(\mu \mathrm{g} / \mathrm{ml})$} \\
\hline & & D1 & D2 & D3 & D4 & D5 & D6 & D7 & D8 & D9 & D10 \\
\hline $\mathbf{M}$ & 12.5 & 6250 & 3125 & 1562.5 & 781.25 & 390.63 & 195.32 & 97.65 & 48.82 & 24.41 & 12.21 \\
\hline $\mathbf{E}$ & 10.25 & 5125 & 2562.5 & 1281.25 & 640.625 & 320.32 & 160.15 & 80.07 & 40.03 & 20.02 & 10.01 \\
\hline$\overline{\mathbf{A}}$ & 17.6 & 8800 & 4400 & 2200 & 1100 & 550 & 275 & 137.5 & 68.75 & 34.38 & 17.19 \\
\hline$\overline{\mathbf{P}}$ & 8.98 & 4490 & 2245 & 1122.5 & 561.25 & 280.63 & 140.32 & 70.16 & 35.08 & 17.54 & 8.77 \\
\hline
\end{tabular}

Where $\mathrm{M}=$ Methanol extract, $\mathrm{E}=$ Ethanol extract, $\mathrm{P}=$ Petroleum ether extract, $\mathrm{A}=$ Acetone extract, $\mathrm{D}=\mathrm{Dilution}$

Table.2 Determination of Minimum Inhibitory Concentration (MIC) of different extracts against pathogenic bacteria strains

\begin{tabular}{|c|c|c|c|c|}
\hline Extract & $\begin{array}{c}\text { Staphylococcus } \\
\text { aureus }\end{array}$ & $\begin{array}{c}\text { Klebsiella } \\
\text { pneumoniae }\end{array}$ & $\begin{array}{c}\text { Pseudomonas } \\
\text { aeruginosa }\end{array}$ & Escherichia coli \\
\hline Methanol & $781.25 \mu \mathrm{g} / \mathrm{ml}^{\mathrm{c}}$ & $1562.5 \mu \mathrm{g} / \mathrm{ml}^{\mathrm{b}}$ & $3125 \mu \mathrm{g} / \mathrm{ml}^{\mathrm{a}}$ & $3125 \mu \mathrm{g} / \mathrm{ml}^{\mathrm{a}}$ \\
\hline Ethanol & $320.32 \mu \mathrm{g} / \mathrm{ml}^{\mathrm{c}}$ & $640.625 \mu \mathrm{g} / \mathrm{ml}^{\mathrm{b}}$ & $1281.25 \mu \mathrm{g} / \mathrm{ml}^{\mathrm{a}}$ & $1281.25 \mu \mathrm{g} / \mathrm{ml}^{\mathrm{a}}$ \\
\hline Petroleum Ether & $2245 \mu \mathrm{g} / \mathrm{ml}^{\mathrm{c}}$ & ND & ND & $4490 \mu \mathrm{g} / \mathrm{ml}^{\mathrm{c}}$ \\
\hline Acetone & $275 \mu \mathrm{g} / \mathrm{ml}^{\mathrm{b}}$ & $68.75 \mu \mathrm{g} / \mathrm{ml}^{\mathrm{c}}$ & $550 \mu \mathrm{g} / \mathrm{ml}^{\mathrm{c}}$ & $68.75 \mu \mathrm{g} / \mathrm{ml}^{\mathrm{a}}$ \\
\hline
\end{tabular}

Values are Mean \pm SEM of Triplicate Samples

Different superscripts in rows are significantly different $(\mathrm{p}<0.05)$

Table.3 Diameter of zone of inhibition at MIC of extract

\begin{tabular}{|c|c|c|c|c|}
\hline $\begin{array}{c}\text { Diameter of ZI } \\
\text { for: }\end{array}$ & $\begin{array}{c}\text { Staphylococcus } \\
\text { aureus }\end{array}$ & $\begin{array}{c}\text { Klebsiella } \\
\text { pneumoniae }\end{array}$ & $\begin{array}{c}\text { Pseudomonas } \\
\text { aeruginosa }\end{array}$ & Escherichia coli \\
\hline Methanol & $5.02 \pm 0.956 \mathrm{~mm}^{\mathrm{b}}$ & $5.32 \pm 0.054 \mathrm{~mm}^{\mathrm{c}}$ & $4.12 \pm 0.026 \mathrm{~mm}^{\mathrm{a}}$ & $4.38 \pm 0.008 \mathrm{~mm}^{\mathrm{a}}$ \\
\hline Ethanol & $6.91 \pm 0.087 \mathrm{~mm}^{\mathrm{b}}$ & $7.68 \pm 0.034 \mathrm{~mm}^{\mathrm{a}}$ & $4.03 \pm 0.023 \mathrm{~mm}^{\mathrm{d}}$ & $5.88 \pm 0.012 \mathrm{~mm}^{\mathrm{c}}$ \\
\hline Petroleum Ether & $3.56 \pm 0.002 \mathrm{~mm}^{\mathrm{a}}$ & ND & ND & $2.76 \pm 0.092 \mathrm{~mm}^{b}$ \\
\hline Acetone & $7.21 \pm 0.029 \mathrm{~mm}^{\mathrm{d}}$ & $7.93 \pm 0.065 \mathrm{~mm}^{\mathrm{a}}$ & $7.58 \pm 0.054 \mathrm{~mm}^{\mathrm{c}}$ & $7.75 \pm 0.12 \mathrm{~mm}^{\mathrm{b}}$ \\
\hline
\end{tabular}

Where ZI = Zone of Inhibition

Values are Mean \pm SEM of Triplicate Samples

Different superscripts are significantly different $(p<0.05)$

Table.4 Diameter zone of inhibition at initial concentration

\begin{tabular}{|c|c|c|c|c|}
\hline $\begin{array}{c}\text { Diameter of } \mathbf{Z I} \\
\text { for: }\end{array}$ & $\begin{array}{c}\text { Staphylococcus } \\
\text { aureus }\end{array}$ & $\begin{array}{c}\text { Klebsiella } \\
\text { pneumoniae }\end{array}$ & $\begin{array}{c}\text { Pseudomonas } \\
\text { aeruginosa }\end{array}$ & Escherichia coli \\
\hline Methanol & $18.52 \pm 0.12 \mathrm{~mm}^{\mathrm{c}}$ & $20.05 \pm 0.07 \mathrm{~mm}^{\mathrm{a}}$ & $17.54 \pm 0.05 \mathrm{~mm}^{\mathrm{d}}$ & $19.97 \pm 0.09 \mathrm{~mm}^{\mathrm{a}}$ \\
\hline Ethanol & $19.12 \pm 0.06 \mathrm{~mm}^{\mathrm{a}}$ & $19 \pm 0.08 \mathrm{~mm}^{\mathrm{a}}$ & $18.44 \pm 0.01 \mathrm{~mm}^{\mathrm{b}}$ & $17.03 \pm 0.07 \mathrm{~mm}^{\mathrm{c}}$ \\
\hline $\begin{array}{c}\text { Petroleum } \\
\text { Ether } \\
\end{array}$ & $5.02 \pm 0.05 \mathrm{~mm}^{\mathrm{a}}$ & ND & ND & $6.56 \pm 0.03 \mathrm{~mm}^{\mathrm{b}}$ \\
\hline Acetone & $20 \pm 0.02 \mathrm{~mm}^{\mathrm{c}}$ & $22.96 \pm 0.08 \mathrm{~mm}^{\mathrm{b}}$ & $25.88 \pm 0.05 \mathrm{~mm}^{\mathrm{a}}$ & $22.14 \pm 0.97 \mathrm{~mm}^{\mathrm{b}}$ \\
\hline
\end{tabular}

Where ZI $=$ Zone of Inhibition; Values are Mean \pm SEM of Triplicate Samples

Different superscripts are significantly different $(p<0.05)$ 
Fig.1 Zones of inhibition at different dilutions of ethanolic extract against Staphylococcus aureus

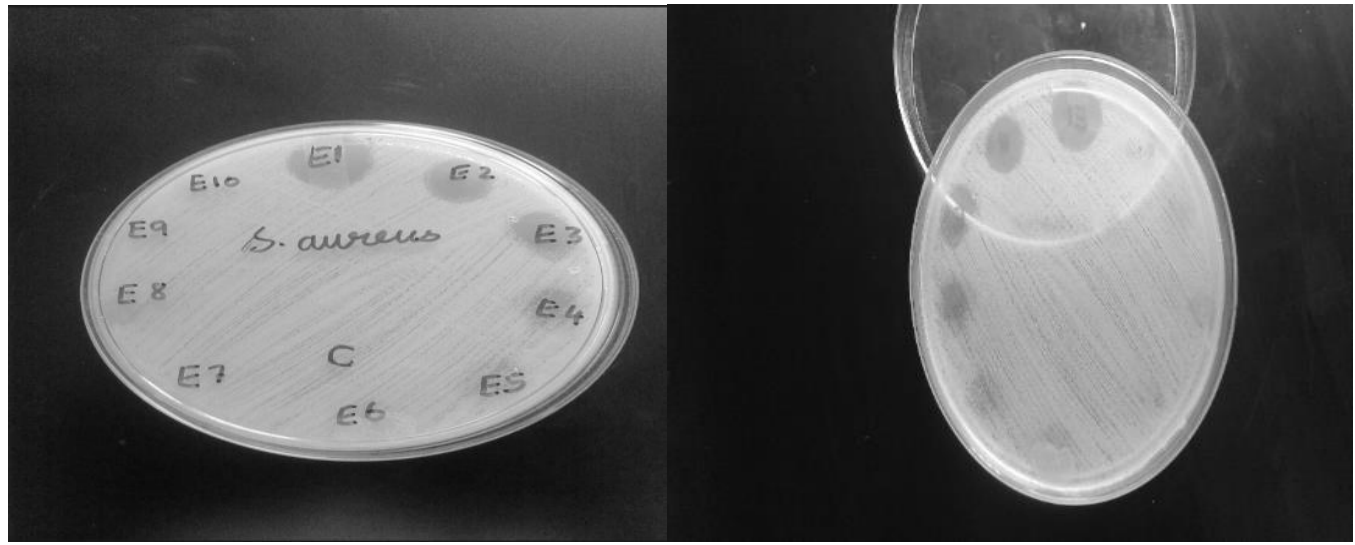

Where $(\mathrm{E} 1>\mathrm{E} 2>. .>\mathrm{E} 10)$, and $\mathrm{C}=$ control

Fig.2 Zones of inhibition at different dilutions of Ethanolic Extract against Pseudomonas aeruginosa

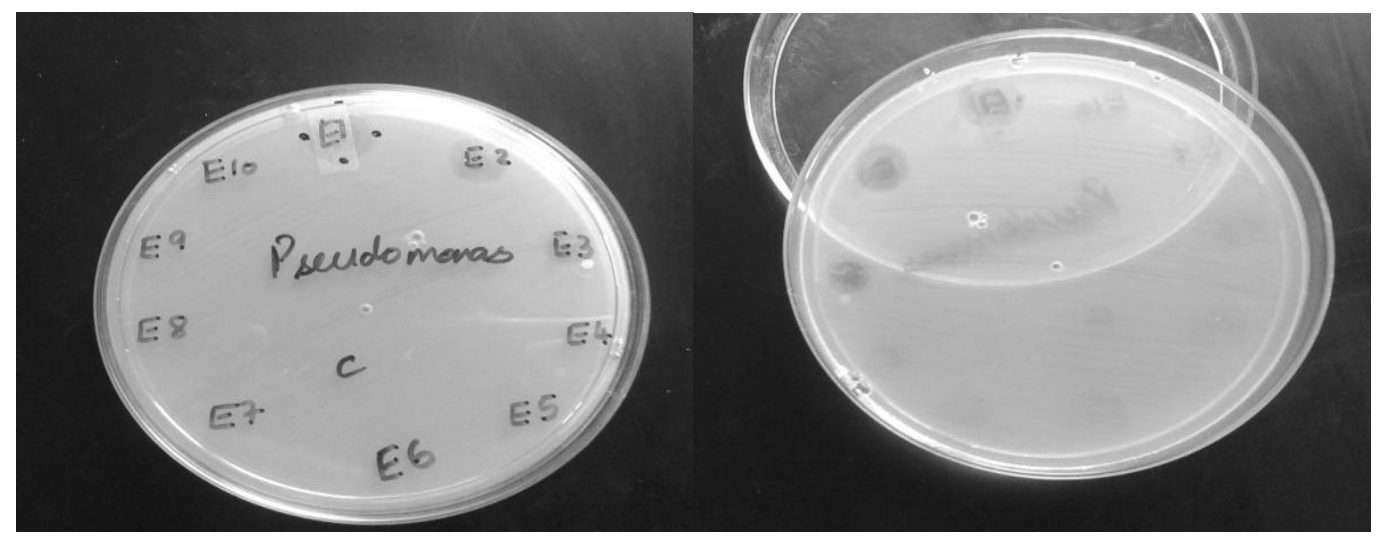

Where $(\mathrm{E} 1>\mathrm{E} 2>. .>\mathrm{E} 10)$, and $\mathrm{C}=$ control

Fig.3 Zones of inhibition at different dilutions of Acetone and Methanol Extract against Escherichia coli
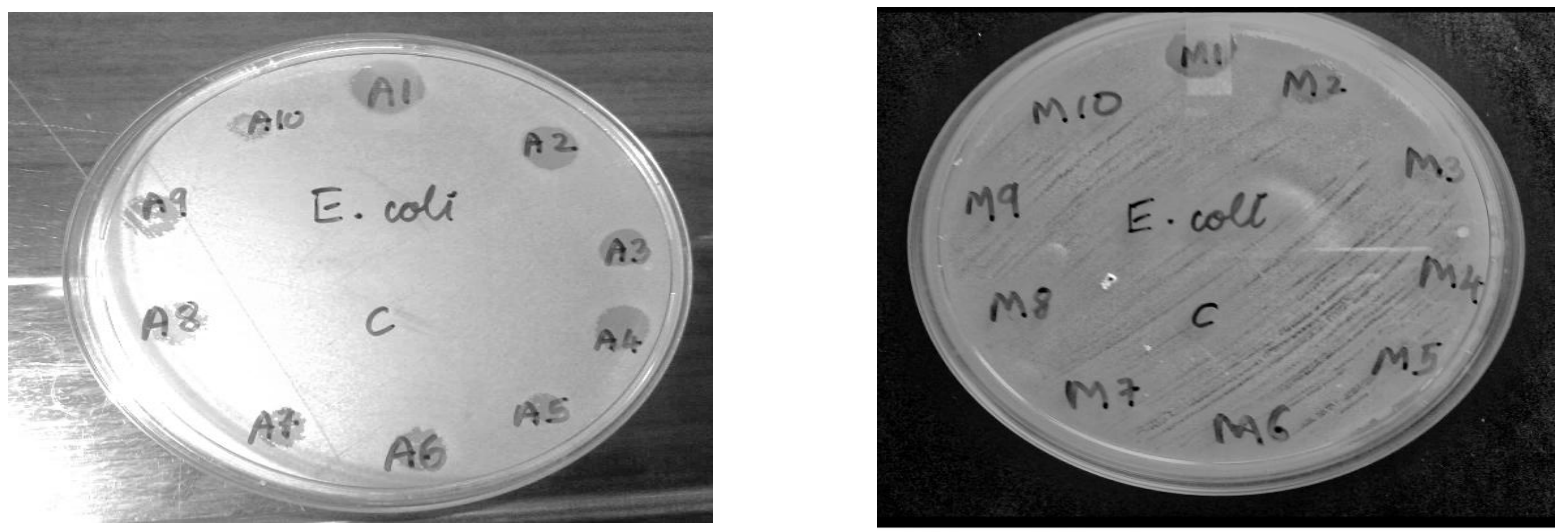

Where $(\mathrm{E} 1>\mathrm{E} 2>. .>\mathrm{E} 10),(\mathrm{M} 1>\mathrm{M} 2>. .>\mathrm{M} 10)$ and $\mathrm{C}=$ control 
Fig.4 Zones of inhibition at different dilutions of methanol and acetone extract against Klebsiella pneumoniae

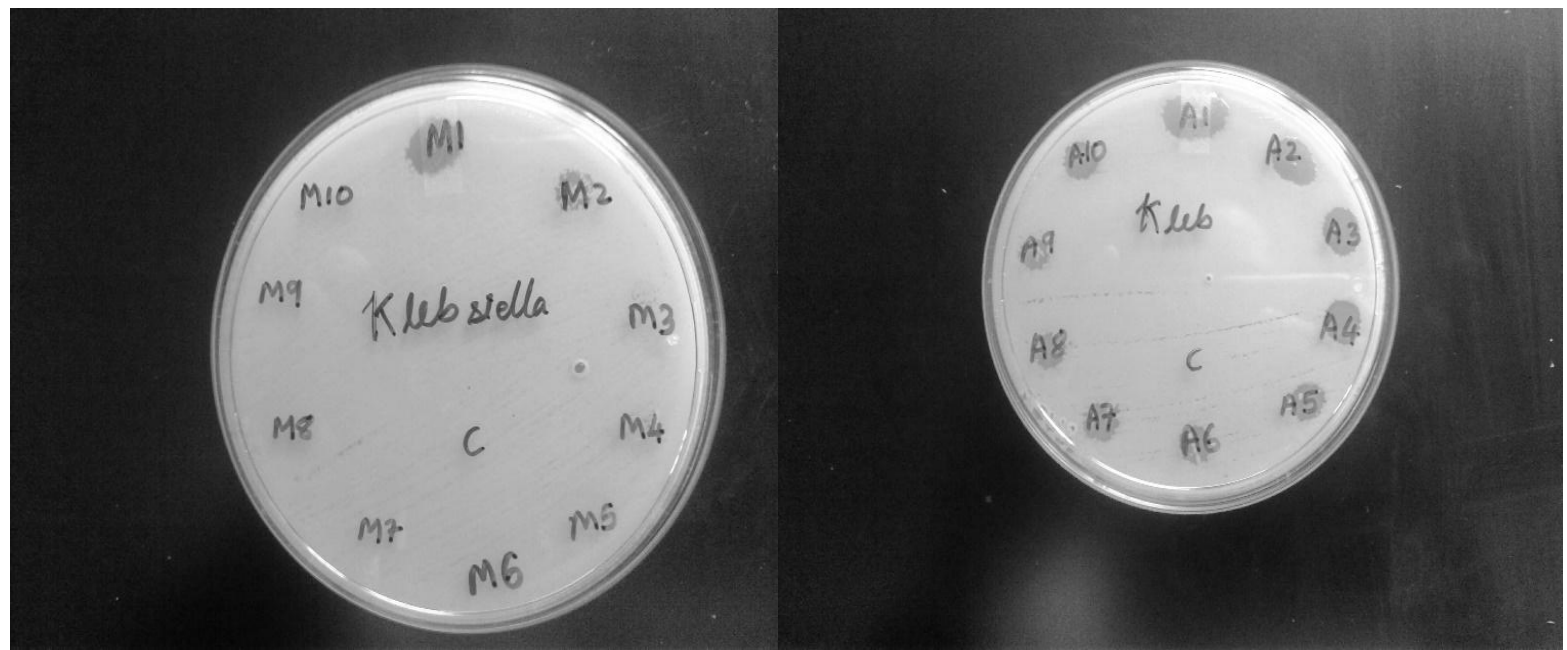

Where $(\mathrm{E} 1>\mathrm{E} 2>. .>\mathrm{E} 10),(\mathrm{M} 1>\mathrm{M} 2>. .>\mathrm{M} 10)$ and $\mathrm{C}=$ control

\section{Antibacterial activity}

The result of the disc diffusion assay, expressed as Zone of Inhibition of bacterial strains and the MICs of the extracts are summarized in Table 2, 3, and 4. Figure 1, 2, 3 and 4 represents the zone of inhibition in different extracts against pathogenic strains. The highest antibacterial activity was obtained with the acetone extract of $C$. reticulata var. Kinnow against Klebsiella pneumoniae and Escherichia coli with inhibition zone diameters of $7.93 \pm 0.065 \mathrm{~mm}$ and $7.75 \pm 0.12$ mmat MIC of $68.75 \mu \mathrm{g} / \mathrm{ml}$, which were not significantly different (P $<0.05)$. The methanol extract showed a zone of inhibition5.02 $\pm 0.956 \mathrm{~mm}$ of at MIC of $781.25 \mu \mathrm{g} / \mathrm{mlin}$ the plate containing the strain of Staphylococcus aureus. The effectiveness of the extracts can be summarized as: Acetone> Methanol > Ethanol > Petroleum Ether. Sterile distilled water, used as negative control, did not show any inhibition against all tested microorganisms.

It has also been observed that Petroleum ether extracts were completely ineffective against Klebsiella pneumoniae and Pseudomonas aeruginosa. Antibacterial activity has been observed in Citrus peel by Dorman et al., (2000) and Mandalari et al., (2007). Espina et al., (2011) previously demonstrated that mandarin peel had greater antimicrobial activity than lemon peel. It was reported that an acetone extract of sea buckthorn seed had higher antibacterial activities than an ethyl acetate extract, although it had the higher phenolic contents than the acetone one. (Turkmen et al., 2007)

It should be taken into account that the area of inhibition of bacterial strain depends on the ability of the extract to diffuse uniformly through the agar (Samy and Ignacimuthu, 1998).

In the case of Staphylococcus aureus, the presence of a simple membrane structure presents little buffering capacity at the interface against localized protonation effects caused by phenolic compounds and polyphenols and can easily cause hyper acidification and therefore disrupt plasma membrane associated $\mathrm{H}^{+}$-ATPase and affect the energy metabolism of the bacterial cell (Du et al., 2011). While it has been noted in 
several studies that Gram positive bacteria are more sensitive to plant extracts than gram negative bacteria, because of the presence of an additional lipopolysaccharide coat, nevertheless there are exceptions in which Gram-negative bacteria are more susceptible than Gram positive towards some natural extracts (Kalemba and Kunicka, 2003). The results obtained in this study are in agreement with this.

The presence of an additional lipopolysaccharide layer along with minor membrane components besides an intact plasma membrane around its cell can have potentially more buffering capacity and hydrophobicity and therefore could prevent the action of simple phenolic compounds and thereby reduce the sensitivity of these bacteria against polyphenols (Du et al., 2011). In the present study, however, it was observed that Acetone extract was highly in inhibiting gram-negative bacteria Klebsiella pneumoniae, Staphylococcus aureus, and Pseudomonas aeruginosa, to different degrees, at varying concentrations of applications. This phenomenon can be attributed to the fact that the acetone extract contained compounds other than simple phenolics, including terpenes limonene, linalool, monoterpenes, and sesquiterpenes.

In the gram negative bacterial cell, lipid constituents of cell membrane are pivotal for its normal functioning for they provide the membrane with its barrier function and play a role in a variety of processes in the bacterial cell. Toxic effects of these components on membrane structure and function have been generally used to explain the antimicrobial action of several essential oils and their monoterpenoid components. As a result of their lipophilic character, monoterpenes will preferentially partition from an aqueous phase into membrane structures (Sikkema et al., 1994). This results in membrane expansion, increased membrane fluidity and permeability, disturbance of membraneembedded proteins, inhibition of respiration, and alteration of ion transport processes. Zengin et al., (2014) have described the effects of selected essential oil components on outer membrane permeability in gramnegative bacteria, thereby proving that terpene and monoterpene uptake is also determined by the permeability of the outer envelope of the target microorganism.

The present study could determine the antibacterial activity exhibited by the extracts of methanol, ethanol, acetone and petroleum ether from Citrus reticulata var. Kinnow against pathogenic strains of Staphylococcus aureus, Escherichia coli, Pseudomonas aeruginosa, and Klebsiella pneumoniae. The highest antibacterial activity was obtained with the acetone extract of $C$. reticulata var. Kinnow against Klebsiella pneumoniae and Escherichia coli and zone of inhibition at Minimum Inhibitory Concentrations were determined successfully. The effectiveness of the extracts was also determined subsequently from the results obtained.

\section{Acknowledgements}

The support provided by the Department of Microbiology, The Institute of Medical Sciences, Banaras Hindu University is gratefully acknowledged.

\section{References}

Alothman, M., Bhat, R., and Karim, A. A. (2009). Antioxidant capacity and phenolic content of selected tropical fruits from Malaysia, extracted with different solvents. Food Chemistry, 115(3), 785-788.

Barreca, D., Bellocco, E., Caristi, C., Leuzzi, U., and Gattuso, G. (2011). Distribution of C-and O-glycosyl flavonoids, (3- 
hydroxy-3-methylglutaryl) glycosyl flavanones and furocoumarins in Citrus aurantium L. juice. Food Chemistry, 124(2), 576-582.

Dorman, H. J. D., and Deans, S. G. (2000). Antimicrobial agents from plants: antibacterial activity of plant volatile oils. Journal of applied microbiology, 88(2), 308-316.

Du, W. X., Olsen, C. W., Avena- Bustillos, R. J., Friedman, M., and McHugh, T. H. (2011). Physical and antibacterial properties of edible films formulated with apple skin polyphenols. Journal of Food Science, 76(2).

Escobedo-Avellaneda, Z., Gutiérrez-Uribe, J., Valdez-Fragoso, A., Torres, J. A., and Welti-Chanes, J. (2014). Phytochemicals and antioxidant activity of juice, flavedo, albedo and comminuted orange. Journal of Functional Foods, 6, 470-481.

Espina, L., Somolinos, M., Lorán, S., Conchello, P., García, D., and Pagán, R. (2011). Chemical composition of commercial citrus fruit essential oils and evaluation of their antimicrobial activity acting alone or in combined processes. Food control, 22(6), 896902.

Hinneburg, I., Dorman, H. D., and Hiltunen, R. (2006). Antioxidant activities of extracts from selected culinary herbs and spices. Food chemistry, 97(1), 122129.

Kalemba, D. A. A. K., and Kunicka, A. (2003). Antibacterial and antifungal properties of essential oils. Current medicinal chemistry, 10(10), 813-829.

Khushwaha, A., Singh, R. P., Gupta, V., and Singh, M. (2012). Antimicrobial properties of peels of citrus fruits. Int $J$ Univers Pharm Life Sci, 2(2), 24-38.

Lapornik, B., Prošek, M., and Wondra, A. G. (2005). Comparison of extracts prepared from plant by-products using different solvents and extraction time. Journal of food engineering, 71(2), 214222.

Mandalari, G., Bennett, R. N., Bisignano, G., Trombetta, D., Saija, A., Faulds, C. B., and Narbad, A. (2007). Antimicrobial activity of flavonoids extracted from bergamot (Citrus bergamia Risso) peel, a byproduct of the essential oil industry. Journal of Applied Microbiology, 103(6), 2056-2064.

Min, K. Y., Kim, H. J., Lee, K. A., Kim, K. T., and Paik, H. D. (2014). Antimicrobial activity of acidhydrolyzed Citrus unshiu peel extract in milk. Journal of dairy science, 97(4), 1955-1960.

Nayak, B., Dahmoune, F., Moussi, K., Remini, H., Dairi, S., Aoun, O., and Khodir, M. (2015). Comparison of microwave, ultrasound and acceleratedassisted solvent extraction for recovery of polyphenols from Citrus sinensis peels. Food chemistry, 187, 507-516.

Otang, W. M., Grierson, D. S., and Afolayan, A. J. (2015). A survey of plants responsible for causing allergic contact dermatitis in the Amathole District, Eastern Cape, South Africa. South African Journal of Botany, 97, 32-39.

Samy, R. P., Ignacimuthu, S., and Sen, A. (1998). Screening of 34 Indian medicinal plants for antibacterial properties. Journal of Ethnopharmacology, 62(2), 173-181.

Sikkema, J., De Bont, J. A., and Poolman, B. (1994). Interactions of cyclic hydrocarbons with biological membranes. Journal of Biological Chemistry, 269(11), 8022-8028.

Singh, M., Gangwar, M., Nath, G., and Singh, S. K. (2014). Synthesis, DNA cleavage and antimicrobial activity of 4thiazolidinones-benzothiazole conjugates. 
Turkmen, N., Sari, F., and Velioglu, Y. S. (2006). Effects of extraction solvents on concentration and antioxidant activity of black and black mate tea polyphenols determined by ferrous tartrate and Folin-Ciocalteu methods. Food chemistry, 99(4), 835-841.

Turkmen, N., Velioglu, Y. S., Sari, F., and Polat, G. (2007). Effect of extraction conditions on measured total polyphenol contents and antioxidant and antibacterial activities of black tea. Molecules, 12(3), 484-496.

Viuda-Martos, M., Ruiz-Navajas, Y., Fernández-López, J., and PérezÁlvarez, J. (2008). Antifungal activity of lemon (Citrus lemon L.), mandarin (Citrus reticulata L.), grapefruit (Citrus paradisi L.) and orange (Citrus sinensis L.) essential oils. Food control, 19(12), 1130-1138.

Yadav, D., Kumar, A., Kumar, P., and Mishra, D. (2015). Antimicrobial properties of black grape (Vitis vinifera L.) peel extracts against antibioticresistant pathogenic bacteria and toxin producing molds. Indian journal of pharmacology, 47(6), 663.

Zengin, H., and Baysal, A. H. (2014). Antibacterial and antioxidant activity of essential oil terpenes against pathogenic and spoilage-forming bacteria and cell structure-activity relationships evaluated by SEM microscopy. Molecules, 19(11), 17773-17798.

\section{How to cite this article:}

Yashaswini, P. and Arvind. 2018. Antimicrobial Properties of Orange (Citrus reticulata var. Kinnow) Peel Extracts against Pathogenic Bacteria. Int.J.Curr.Microbiol.App.Sci. 7(03): 737746. doi: https://doi.org/10.20546/ijcmas.2018.703.086 